\title{
Comparative Analysis of Retinal Ganglion Cell Topography and Behavioral Ecology in Australian Marsupials
}

\author{
Análisis Comparativo de la Topografía de las Células Ganglionares de la \\ Retina y Ecología del Comportamiento en Marsupiales Australianos
}

\author{
Navarro-Sempere, A.; Segovia Y. \& García M.
}

NAVARRO-SEMPERE, A.; SEGOVIA, Y. \& GARCÍA, M. Comparative analysis of retinal ganglion cell topography and behavioral ecology in australian marsupials. Int. J. Morphol., 36(1):248-257, 2018.

SUMMARY: The retina of vertebrates shows adaptations to the visual environment in which they evolve. Thus, there exists a relationship between the topographic distribution of retinal cells, the adaptive strategies employed, and habitat, so that, analyses of retinal ganglion cell topography provide information about the behavioral ecology of a species. Although these relationships are well documented in many vertebrates, including mammals, for species within the marsupial order, they are not well understood. However, marsupials represent an ideal group for comparative analyses of interspecific variations in the mammalian visual system because they contain species that vary in both lifestyle and habitat preference. In this paper the interspecific variation in retinal ganglion cell topography in 13 species of Australian marsupials is reviewed. The species that live in open habitats have well-defined elongated visual streaks. In contrast, forest-dwelling marsupials have poorly defined visual streaks and a more radially symmetrical arrangement of retinal ganglion cell (RGC) isodensity contours. However, the organization and degree of elongation of the visual streak varies considerably among species. The results indicate that the apparent interspecific variation is associated with activity pattern and habitat as opposed to the phylogenetic relationships among species.

KEY WORDS: Marsupial retina; Visual ecology; Ganglion cell topography.

\section{INTRODUCTION}

Due to the important role that vision plays in the survival of the majority of vertebrates, visual system has evolved extremely selective in response to the amount of environmental light, the ecological niche and the range of habitats available (Hughes, 1977; Collins, 1999, 2008). For this reason, there is a great variety of vision models in vertebrates: there are reptile and birds that can see in color (Inzunza et al., 1991; Vorobyev, 2003), while other marine vertebrates, such as sharks, either do not have this ability (Schluessel et al., 2014) or their spectral sensitivity is extremely low, for example in cetaceans and pinnipeds (Peichl et al., 2001). Opposite to predatory species that display a high spatial resolution (Temple et al., 2010; She et al., 2011), nocturnal and species that live in dim-light environments, spatial resolution is sacrificed in order to maximising light sensitivity (Collin \& Partridge, 1996; Warrant, 2004; Mengual et al., 2014, 2015).

Light intensity, visibility, size and mobility of prey, feeding strategies, and then, ecological niche have contributed to different adaptations in both optical components and number and distribution of retinal cells, particularly in photoreceptors and ganglion cells (Walls, 1942; Meyer, 1977; Hughes, 1977; Schiviz et al., 2008; Wagner et al., 1998; Collin, 1999; Moore et al., 2012). Thus, knowledge of the topography of retinal cells together with the position of the eyes in the head, provided a great deal of information on habitat and adaptations in the use of the visual field of each species (Hughes, 1977; Collin, 2008). More specifically, the distribution of ganglion cells in isodensity contours and the presence of specializations in the retina, (areas with a high density of photoreceptors and ganglion cells) which provide high resolution power (Walls; Meyer; Hughes, 1977; Collin \& Pettigrew 1988a, 1988b), revealed the importance that each species assigns to the specific areas of its vision field in order to optimising the visual acuity (Hughes, 1975, 1977, 1985; Collin \& Pettigrew 1988a, 1988b; Collin, 1999). Therefore, the study of ganglion cell distribution suggests a strong link between the eye and the behaviour of the animal. 
In vertebrates, three different types of retinal specializations have been identified: fovea, area centralis and visual streak (Walls; Meyer). The fovea is a depression in the retina with a higher density of photoreceptors surrounded by a higher density of ganglion cells, and is considered to be the specialization that gives the most visual acuity. In this area, the internal layers of the retina are laterally flattened with the aim of presenting the least possible barrier to the light that passes to the photoreceptors (Inzunza et al.). The area centralis is a concentric increase in ganglion cell density without displacing the internal layers. Finally, the visual streak is a band-like area extending horizontally across the retina allowing higher spatial sampling of a panoramic visual field (Walls; Meyer; Hughes, 1977).

Austin Hughes (1977) analysed the topography of the retinal ganglion cells in various species of mammals with particular focus on their density, the density gradient towards the periphery, the presence or not of the visual streak and/or the area centralis, and he concluded that the differences in these parameters were closely related to the animal's lifestyle. He proposed five different distribution patterns of ganglion cells, divided into two groups: those that show isodensity contours with a high degree of radial symmetry without the presence of visual streak; and mixed retinas in which this band is combined, or not, with an area. These ganglion distribution patterns are as follows:

a) Low ganglion cell density of with a little centroperipheral density gradient. This distribution is typical in small nocturnal animals which inhabit scrubland, such as mice and guinea pigs.

b) High ganglion cell density with a little centroperipheral density gradient. This distribution is characteristic of predominantly diurnal animals, such as squirrels.

c) Steep centroperipheral density gradient. Such distribution that occurs in primates, is associated with a fovea.

d) Central or temporal area superposed on a visual streak. A good example of the first case is the retina of cats, dogs and other carnivores. In the case of herbivores, such as goats, horses and red kangaroos the area is found in the temporal part which allows the visual axis to remain on the parasagittal plane in spite of the lateral position of the eyes.

e) Visual streak not associated with an area, such as in the case of rabbits.

Since Hughes proposed the different distribution models for ganglion cells and the "terrain theory", a number research papers have provided data on the topography of these cells in a range of vertebrate species. However, there have been few studies focusing on the relationship between retinal ganglion cells and the behaviour of marsupials.
Marsupials (class: Mammalia, subclass: Theria, infraclass: Marsupialia) separated away from the placentals around 130 million years ago, and began their divergence around 70 million years ago. However, the evolutionary relationships between the 7 orders of marsupials are still not really understood (Nilsson et al., 2010; Bennett, 2012). Research into the origins of marsupials show that the oldest fossil is Sinodelphys szalayi which lived in China 125 million years ago (Luo et al., 2003). 100 million years ago, the supercontinent Pangea was in the process of separating itself into the northern and southern continents of Laurasia and Gondwana. The marsupials probably evolved in North America and then expanded towards South America and Australia at the beginning of the Terciary era. During this migration process, the majority of the North American marsupials became extinct, with the exception of Didelphis virginiana (Nilsson et al., 2004).

There are currently 331 species of marsupials divided into 18 families, of which 200 species live in Australia. The rest of the species are distributed over South America (around 90 species), and North America (only 1 species) (Bennett). When Australia became an isolated landmass, as well as simply surviving, the marsupials diversified and evolved, which allowed them to colonize a multitude of ecological niches. In spite of the diversity of habitats to which they have adapted, they are considerably less diverse than the placentals in terms of number of groups, physical appearance, and lifestyles (Bennett). There are no marsupials that are specialized runners, live in water, or are capable of flight. However, some of them fill ecological niches very similar to some mammalian placentals, and which show superficial similarities (Bennett). Australian marsupials are very diverse in habitat preference, lifestyle and in their food strategy. Not only can it be divided into herbivores and carnivores, but some species can feed on pollen, seeds, fungi, termites, etc. Because they exhibit variation in both activity pattern and habitat preference, marsupials are ideal for comparative analyses of ganglion cells topography.

The objective of this review is to provide a synthesis of the data currently existing in the literature on visual acuity in marsupials with the aim of comparing and relating ganglion cell topography with the adaptation of the species to their lifestyle and, in turn with their taxonomic classification.

\section{MATERIAL AND METHOD}

This section is divided into three parts. Firstly, a bibliographic search (from Web of Science and Scopus Databases) of research articles studying ganglion cell topography in Australian marsupials is presented. As such, 
the species covered in this work are the following: Smithopsis crassicaudata, Tarsipes rostratus, Macropus eugenii, Macropus rufus, Dendrolagus dorianus, Sarcophilus harrissi, Isoodon obesulus, Lasiorhinus latifrons, Phascolarctos cinereus, Thylogale billarderii, Dasyurus hallucatus, Trichosurus vulpecula and Setonix brachyurus. Following this, the results of a bibliographic search are presented in order to understand the descriptions and distribution of each species, their diet and behaviour. Finally, topographical maps of the ganglion cells of each of the species and a classification of the different distribution patterns according Hughes' criteria are presented.

\section{RESULTS}

Taxonomic classification and geographic distribution. Figure 1 shows a cladogram representing the relationships between the principal orders of marsupials (Based on Cardillo et al., 2004). The 331 current species of marsupials are grouped into seven orders (there are also 3 known orders that are extinct). Marsupials are very common in Australia, but around 90 species can only be found in South America, and only one in North America. From among the Australian marsupials, the object of our study, the Diprotodontia order includes more than 100 species, ranging from kangaroos to wombats. Fig. 2 shows a map of Oceania detailing the distribution of the different species studied.

\section{Behaviour, lifestyle and habitat of the Australian marsupials studied}

Sminthopsis crassicaudata (Gould 1884). This is a poliprotodont marsupial mouse of the family Dasyuridae. It measures 60-90 mm, with a tail of around 45-70 mm in which it stores its fat reserves for periods of food scarcity (Ride, 1970). It is a carnivorous animal feeding mainly on insects,

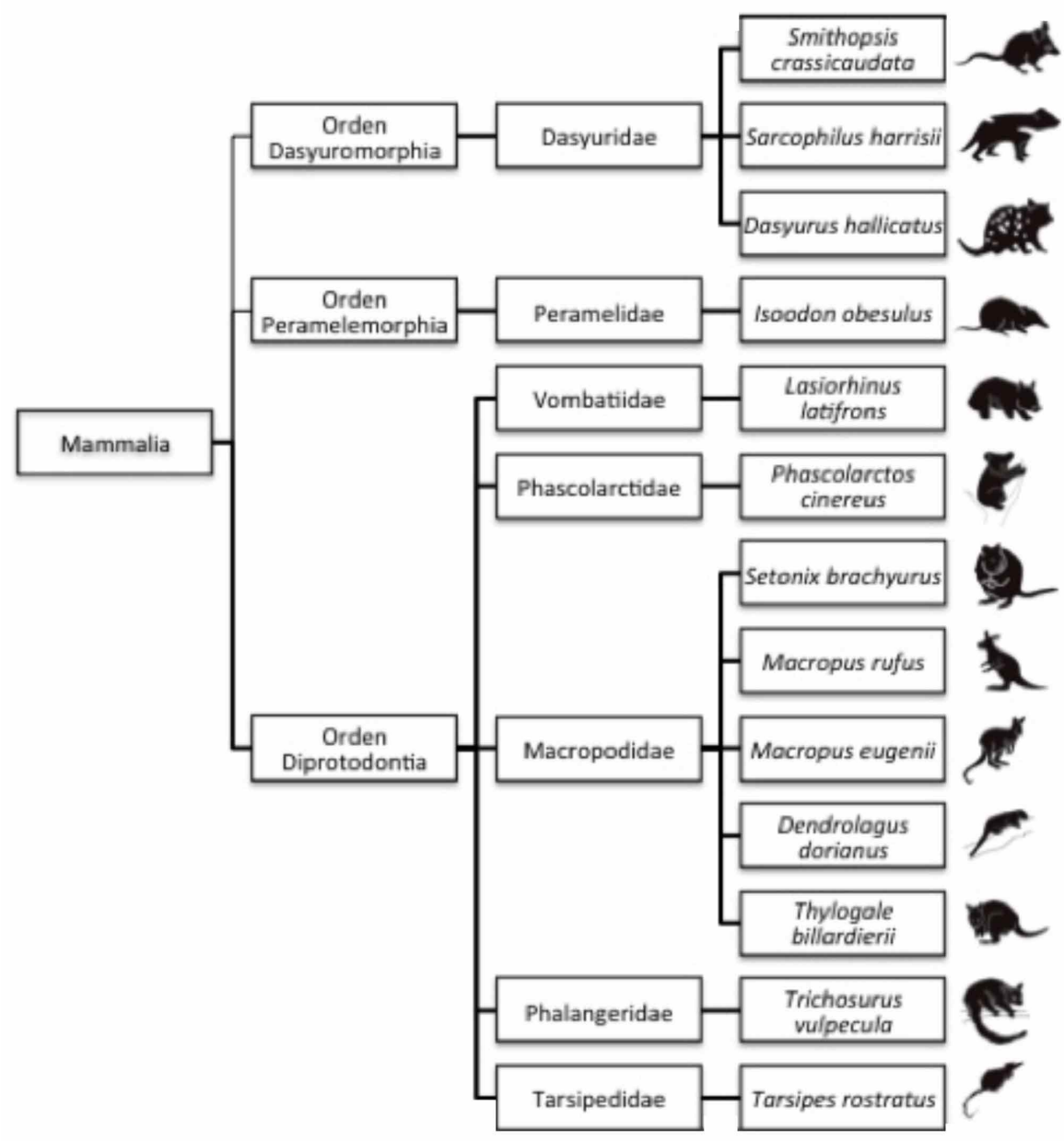

Fig. 1. Cladogram representing the relationships between the principal orders of Marsupials (Based on Cardillo et al., 2004). 
insect larvae, small reptiles and amphibians. It typically inhabits areas of low scrubland such as pasture or cultivated areas. (Dickman et al., 1995). It is a nocturnally active animal (Morton, 1978), avoiding the higher daytime temperatures. In periods when food is scarce its activity time is reduced (Geiser et al., 1984).

Tarsipes rostratus (Gervais \& Verreaux, 1842). This is a diprodont marsupial, the only member of the Tarsipedidae family (Aplin \& Archer, 1987). It measures between 70-90 $\mathrm{mm}$ while its tail can reach up to $105 \mathrm{~mm}$. The tail is prehensile and is used to climb plants and flowers. It feeds on nectar and pollen from a wide variety of plants and flowers (Russell \& Rentree, 1989). It plays an important role as a

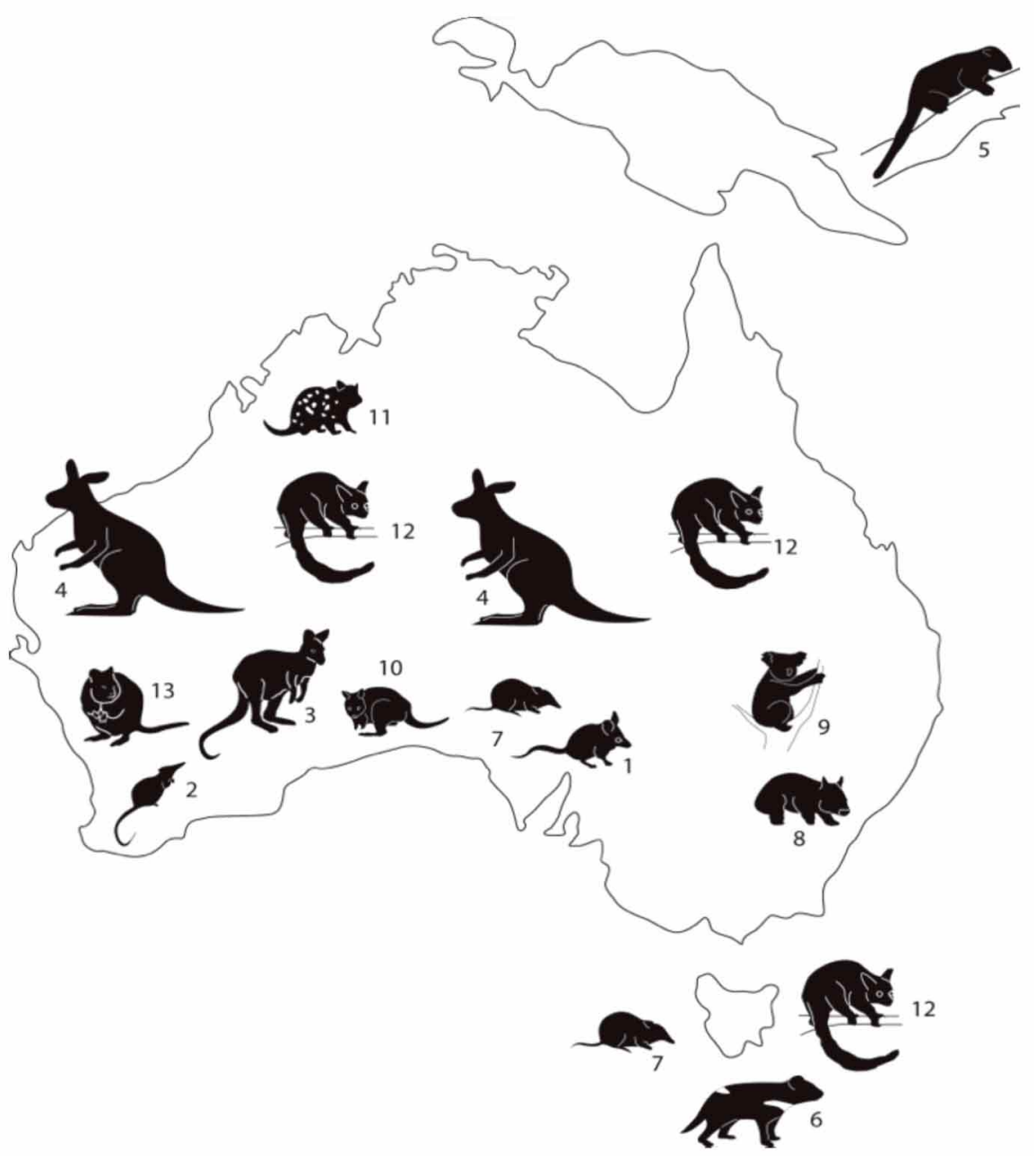

Fig. 2. Map of Oceania detailing the distribution of the different species we have studied. Fig., 1: Sminthopsis crassicaudata; 2. Tarsipes rostratus; 3: Macropus eugenii; 4: Macropus rufus; 5: Dendrolagus dorianus; 6: Sarcophilus harrisii; 7: Isoodon obesulus; 8: Lasiorhinus latifrons; 9: Phascolarctos cinereus; 10: Thilogale billardierii; 11: Dasyurus hallucatus; 12: Didelphis vulpecula; 13: Setonix brachyurus. pollinator for different plants (Wooller \& Wooler, 2003). When food is scarce and temperatures are low, it may hibernate for a short period of time (Withers et al., 1990). It inhabits heathlands and brush of medium elevation (Dunlop et al., 1994) but is mainly active on plants and the branches of bushes and as such is a tree-dwelling animal (Everaardt, 2003).

Macropus eugenii (Desmarest, 1817). This is a diprodont marsupial of the Macropodidae family. It can reach almost $70 \mathrm{~cm}$ in length, with a tail $40 \mathrm{~cm}$ long (Jarman, 1991). It is strictly herbivorous, eating mainly leaves, for which purpose its upper members have adapted (Lentle, 1998). It is a twilight animal, roaming open areas mainly at dawn and dusk. During the day it inhabits medium sized bushes in scrubland type areas (Wong et al., 1986). Its main predators are the dingo (Canis lupus dingo), a sub-species of wolf unique to Australia, and the wedge-tailed eagle (Aquila audax) among others.

Macropus rufus (Desmarest, 1822). This is a diprotodont marsupial that belongs to the Macropodidae family. Together with the grey kangaroo (Macropus giganteus), it is the largest living marsupial in the world (Grzimek, 1975). Its body can measure up to $105 \mathrm{~cm}$ in length for females and $160 \mathrm{~cm}$ for males. When standing upright it can attain a height of 180 $\mathrm{cm}$. In females the length of the tail can reach $85 \mathrm{~cm}$, and in males 120 $\mathrm{cm}$ (Nowak, 1999). The males have a reddish colouring from which the name originates, however, the females have a more greyish colouring. It is a strictly herbivorous animal, feeding mainly on pasture and grass shoots (Cronin, 2008). Its hind legs are adapted to jump, and so can cover large distances in search of food (Nowak). It prefers to roam over open land that is free of trees and bushes but often seeks shelter in the shade of trees when seeking refuge from high daytime temperatures (Nowak). The red kangaroo is a twilight / nocturnal animal (Cronin). 
Dendrolagus dorianus (Müller, 1840). This is a diprodont marsupial which, as with the two previous species, belongs to the Macropodidae family. From head to tail it measures between 51 and $78 \mathrm{~cm}$, of which between 40 and $66 \mathrm{~cm}$ are the tail (Flannery \& Seri, 1990). It inhabits the jungles of New Guinea and its main means of locomotion is jumping and climbing trees. Its diet consists of leaves, flowers and fruits of the trees in which it lives (Flannery \& Seri). This is a generally solitary and nocturnal animal (Procter-Gray \& Ganslosser, 1986).

Sarcophilus harrisii (Boitard, 1841). This marsupial belongs to the Dasyuridae family. It has a body length of between 50 and $80 \mathrm{~cm}$, with a tail that measures between 23 and $30 \mathrm{~cm}$. The females are a little smaller than the males (Green, 1967). In spite of their small size, with the extinction of the marsupial wolf (Thylacinus cynocephalus) it became the largest living carnivorous marsupial. Its strong mandibular musculature give it the strongest bite (in relation to body mass), of any mammal living at present (Wroe et al., 2005). It feeds on wallabies, wombats, Tasmanian pademelon, rabbits and sheep. It feeds on both live animals and carrion. It has also been known to feed on insects, snakes and amphibians (Nowak). This species S. harrisii inhabits forests, jungles and scrub brush, although they prefer open to dense wooded areas and dry to humid areas (Jones \& Barmuta, 2000). It is a nocturnal animal, and it is thought to have adapted to this lifestyle to avoid predators. It is generally a solitary animal.

Isoodon obesulus (Shaw, 1979). This marsupial belongs to the Peramelidae family. It is characterized by short, squat bodies, pointed snouts, slim legs and fairly short tails. Isoodon obesulus can reach lengths of $33 \mathrm{~cm}$ with tails of up to $12 \mathrm{~cm}$ (Nowak). These are omnivorous animals, feeding mainly insects and worms, as well as fruits and seeds, etc. They inhabit areas covered in dense vegetation such as tall grasses and bushes. They nest on the ground and are generally found close to rivers. They use their sharp claws and pointed snouts to dig for food. It is a species that is active during both night and day and is generally solitary (Paull, 2008).

Lasiorhinus latifrons (Owen, 1845). This is a diprodont marsupial of the Vombatidae family. L. latifrons is characterized by their muscular appearance, small size and short legs (Wells, 1989). They generally measure between 77 and $90 \mathrm{~cm}$, have a short tail which barely reaches $5 \mathrm{~cm}$ and is hidden beneath its fur. Thanks to its robust constitution and the fact that it has five digits on each leg, it is well adapted for digging (Nowak). L. latifrons is a herbivorous animal, and its preferred food is the green shoots of the plants in the family Stipa sp. (Wells, 1995). This species generally inhabits semi-arid areas, such as open woodland, savannah, pastures and plains. It is a solitary, nocturnal animal that spends the daytime in burrows that it digs itself (Taggart \& TempleSmith, 2008).

Phascolarctos cinereus (Goldfuss, 1817). This diprodont marsupial belongs to the Phascolarctidae family. P. cinereus measures between 60 and $80 \mathrm{~cm}$, has a round, stocky body, a spoon-shaped nose and a vestigial tail (Nowak). It is strictly herbivorous, feeding mainly on the leave of Eucaliptus $s p$. As eucalyptus leaves give little energy, $P$. cinereus sleeps up to 20 hours a day, and the time spent awake during the night is used to feed in order to build up reserves of energy (Moyal, 2008). They are solitary animals that only group together during the breeding season. The only bond with this species is between mothers and dependent offspring.

Thylogale billardierii (Desmarest, 1822). The marsupials of the Thylogale sp. class are small kangaroos belonging to the Macropodidae family. These can be differentiated from M. eugenii by their tails, which are slimmer, smaller and have less hair (Nowak). T. billardierii generally measures around 1 meter in length including the tail. This is a herbivorous marsupial whose diet is based on grass, plant shoots and some flowers. They inhabit areas of dense vegetation, such as jungles and rain forests. They are nocturnal, often feeding during the night in open areas; however they seldom stray too far from the refuge of the

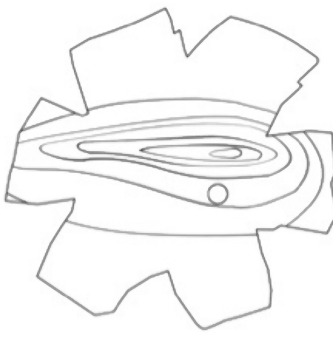

1.- Well-defined visual streak

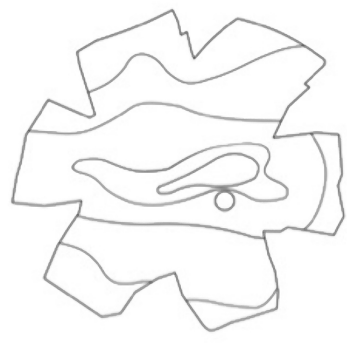

2.-Weak visual streak

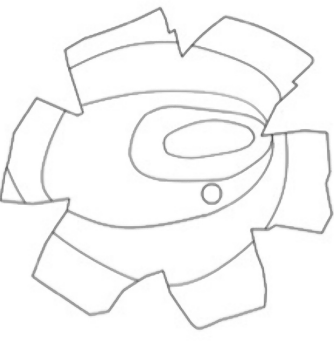

3.- Radial symmetry
Fig. 3. Different distribution patterns of ganglion cells: 1) well-defined visual streak; 2) weak visual streak; and 3) radially symmetrical arrangement of RGCs isodensity contours. 
jungle. (Johnson, 1980). They differ from M. eugenii, T. billardierii in that they are solitary animals, only forming groups during the breeding season or to forage. Individuals do not maintain strong bonds (Johnson \& Rose, 1995).

Dasyurus hallucatus (Gould, 1842). This is a polyprotodont marsupial of the Dasyuridae family that is rodent-like in appearance (Oakwood, 2002). They are characterized by sexual dimorphism. They generally measure between 12 and $30 \mathrm{~cm}$ and have a long tail that can reach up to $30 \mathrm{~cm}$ in length. They are brown or dark grey in colour with white patches. They are carnivorous marsupials, feeding mainly on small mammals, frogs and reptiles, although they will also eat fruit. They are solitary, nocturnal animals that inhabit open woodland, usually of eucalyptus, and rocky areas. They are expert climbers of rocks and hollow tree trunks (Collins, 1973).

Trichosurus vulpecula (Kerr, 1792). This is a diprotodont marsupial of the Phalangeridae family. Its body measures between 32 and $58 \mathrm{~cm}$ in length and has different colorations ranging from grey to cream, with intermediate stages of black and brown. Moreover, Trichosurus vulpecula shows sexual dimorphism in terms of pigmentation (Nowak). This is a herbivorous animal whose diet consists of flowers, leaves, seeds and fruit, although they could eat small insects and occasionally young birds (Nowak). The Australian possum is a mainly tree-dwelling marsupial, but it can also be found in open areas, often inhabiting the caves and burrows of other animals. It is a solitary, nocturnal animal. Animals of the same sex avoid contact using vocal and olfactory communication. The young become independent from their mothers at between 8 and 18 months (Nowak).

Setonix brachyurus (Quoy y Gaimard, 1830). This a diprotodont marsupial of the Macropodidae family. It is distributed over the south-east of Australia, including the islands of Rottnest and Bald (Ride). The head and body measure between 475 and $600 \mathrm{~mm}$ and the tail is between 250 and $350 \mathrm{~mm}$. It is brown or grey in colour, sometimes showing a reddish hue. Its habitat is restricted to areas of dense vegetation, often taking shelter from the heat in shaded areas (Nicholls, 1971). This is a herbivorous, nocturnal animal. S. brachyurus form family groups in which there is one dominant male followed by a stable hierarchy (Kitchener, 1972).

Analysis of distribution of ganglion cells, retinal

Table I. Comparison of the ganglion cell density gradients in the center and periphery of the retina, topographic patterns of ganglion cells, presence of specialization and maximum density peak.

\begin{tabular}{|c|c|c|c|c|c|c|c|c|}
\hline Reference & Specie & $\begin{array}{c}\text { Peripheric } \\
\text { density } \\
(\mathrm{Pd}) \\
\left(\mathrm{Cell} / \mathrm{mm}^{2}\right)\end{array}$ & $\begin{array}{c}\text { Central } \\
\text { density } \\
(\mathrm{Cd}) \\
\left(\mathrm{Cells} / \mathrm{mm}^{2}\right)\end{array}$ & $\begin{array}{l}\text { Gradient } \\
\mathrm{Cd} / \mathrm{Pd}\end{array}$ & $\begin{array}{c}\text { Peak cell } \\
\text { density } \\
(\text { cell/ } \\
\left.\mathrm{mm}^{2}\right)\end{array}$ & $\begin{array}{l}\text { Topographic } \\
\text { patterns of } \\
\text { ganglion } \\
\text { cells }\end{array}$ & $\begin{array}{l}\text { Presence } \\
\text { of area } \\
\text { centralis }\end{array}$ & $\begin{array}{l}\text { Way of } \\
\text { fe eding }\end{array}$ \\
\hline Hughes, 1975 & $\begin{array}{l}\text { Macropus } \\
\text { rufus }\end{array}$ & 250 & 6000 & $24 X$ & 6000 & $\begin{array}{l}\text { Well-defined } \\
\text { visual streak }\end{array}$ & No & $\begin{array}{c}\text { Do not use } \\
\text { upper } \\
\text { members }\end{array}$ \\
\hline Hughes, 1975 & $\begin{array}{l}\text { Dendrolagus } \\
\text { dorianus }\end{array}$ & 500 & 4000 & $8 \mathrm{X}$ & 4000 & $\begin{array}{c}\text { Radial } \\
\text { symmetry }\end{array}$ & Yes & $\begin{array}{l}\text { Use upper } \\
\text { limbs }\end{array}$ \\
\hline $\begin{array}{l}\text { Freeman \& Tancred, } \\
1978\end{array}$ & $\begin{array}{l}\text { Trichosurus } \\
\text { vulpecula }\end{array}$ & 500 & 4000 & $8 \mathrm{X}$ & 5470 & $\begin{array}{l}\text { Radial } \\
\text { symmetry }\end{array}$ & Yes & $\begin{array}{l}\text { Use upper } \\
\text { limbs }\end{array}$ \\
\hline Tancred, 1981 & $\begin{array}{l}\text { Lasiorhinus } \\
\text { latifrons }\end{array}$ & 250 & 2000 & $8 X$ & 3200 & $\begin{array}{l}\text { Well-defined } \\
\text { visual streak }\end{array}$ & No & $\begin{array}{l}\text { Do not use } \\
\text { upper } \\
\text { members }\end{array}$ \\
\hline Tancred, 1981 & $\begin{array}{l}\text { Sarcophilus } \\
\text { harrisii }\end{array}$ & 250 & 4000 & $16 \mathrm{X}$ & 4700 & $\begin{array}{l}\text { Weak visual } \\
\text { streak }\end{array}$ & Yess & $\begin{array}{l}\text { Use upper } \\
\text { limbs }\end{array}$ \\
\hline Tancred, 1981 & $\begin{array}{l}\text { Isoodon } \\
\text { obesulus }\end{array}$ & 500 & 2000 & $4 \mathrm{X}$ & 2352 & $\begin{array}{l}\text { Weak visual } \\
\text { streak }\end{array}$ & $\begin{array}{c}\text { Yes, less } \\
\text { specialize } \\
\text { d. }\end{array}$ & $\begin{array}{c}\text { Do not use } \\
\text { upper } \\
\text { members }\end{array}$ \\
\hline Tancred, 1981 & $\begin{array}{l}\text { Thilogale } \\
\text { billardierii }\end{array}$ & 500 & 4000 & $8 X$ & 4928 & $\begin{array}{l}\text { Weak visual } \\
\text { streak }\end{array}$ & Yes & $\begin{array}{l}\text { Use upper } \\
\text { limbs }\end{array}$ \\
\hline Beazley \& Dunlop, 1983 & $\begin{array}{l}\text { Setonix } \\
\text { brachyurus }\end{array}$ & 500 & 5000 & $10 \mathrm{X}$ & 5000 & $\begin{array}{c}\text { Radial } \\
\text { symmetry }\end{array}$ & Yes & $\begin{array}{l}\text { Use upper } \\
\text { limbs }\end{array}$ \\
\hline Harman etal., 1986 & $\begin{array}{l}\text { Dasyurus } \\
\text { hallicatus }\end{array}$ & 1200 & 2600 & $2,16 \mathrm{X}$ & 2600 & $\begin{array}{l}\text { Weak visual } \\
\text { streak }\end{array}$ & Yes & $\begin{array}{l}\text { Use upper } \\
\text { limbs }\end{array}$ \\
\hline Wong et al., 1986 & $\begin{array}{l}\text { Macropus } \\
\text { eugenii }\end{array}$ & 250 & 5000 & $20 \mathrm{X}$ & 5600 & $\begin{array}{l}\text { Well-defined } \\
\text { visual streak }\end{array}$ & Yes & $\begin{array}{l}\text { Use upper } \\
\text { members }\end{array}$ \\
\hline Dunlop et al., 1994 & $\begin{array}{l}\text { Tarsipes } \\
\text { rostratus }\end{array}$ & 2000 & 9000 & $4,5 \mathrm{X}$ & 9000 & $\begin{array}{l}\text { Radial } \\
\text { symmetry }\end{array}$ & $\begin{array}{c}\text { Yes, } \\
\text { weak. }\end{array}$ & $\begin{array}{l}\text { Use upper } \\
\text { limbs }\end{array}$ \\
\hline Arrese et al., 1999 & $\begin{array}{l}\text { Smithopsis } \\
\text { crassicaudata }\end{array}$ & 3000 & 8000 & $2,67 X$ & 8300 & $\begin{array}{l}\text { Well-defined } \\
\text { visual streak }\end{array}$ & Yes & $\begin{array}{l}\text { Use upper } \\
\text { members }\end{array}$ \\
\hline Schmidt, 2002 & $\begin{array}{l}\text { Phascolarctos } \\
\text { cinereus }\end{array}$ & 500 & 1400 & $2,8 \mathrm{X}$ & 1480 & $\begin{array}{l}\text { Radial } \\
\text { symmetry }\end{array}$ & No & $\begin{array}{c}\text { Do not use } \\
\text { upper } \\
\text { members }\end{array}$ \\
\hline
\end{tabular}


specializations and visual acuity. From the topographic representation of ganglion cell for each of the species (taken from reviewed articles), it is possible to classify distribution patterns of ganglion cells into 3 groups: 1) those showing a well-defined visual streak; 2) those showing a weak visual streak; and 3) those that show a radially symmetrical arrangement of RGCs isodensity contours (Fig. 3). These three distribution models may or may not be combined with an area centralis. A comparison is also made in this work between the central peripheral gradient of ganglion cells of the different species, so that the species that have a more pronounced gradient depend more on specialization of the retina to observe objects (Moore et al., 2012). Finally, the maximum density peak of ganglion cells is an indispensable parameter as it is used to calculate visual acuity in a species (Hughes, 1977; Pettigrew et al., 1988). However, this value is only known for 5 of the species analysed here. This data is shown in Table I.

\section{DISCUSSION}

After classifying the different species according to ganglion cell topography type and an exhaustive analysis of their ecology, it seems clear all those species that prefer more barren areas over areas with denser vegetation, show a topography with a well-developed horizontal visual streak, as is the case with Lasiorhinus latifrons, Macropus rufus, Macropus eugenii and Smithopsis crassicaudata. It has been suggested that visual streaks, which concentrates a large quantity of ganglion cells, may be important for orientating the eye with respect to the horizon (Meyer). The terrestrial objects of the animals that live in open habitats dominated by a horizon as desert or grasslands, are presented only on the horizontal plane, in such way that a fixed relationship between the image of the horizon and the corresponding area of the retina is needed. When these animals look directly ahead, the lower part of the field of vision is taken up by the ground, the upper part by the sky, and in the centre they visualize a panorama of the visual field (Hughes, 1977). In functional terms, the horizontal streak improves visual sampling across the horizon, thereby allowing the detection of predators, prey, or conspecifics without the need for extensive head and/or eye movements (Hughes, 1977; Collin, 1999). This means that the visual streak allows rapid detection of the presence of a predator, prey, or in the case of $M$. rufus allows the control of the rest of the family group while the individual is feeding, for example.

On the other hand, the marsupials whose habitat is more densely covered in vegetation, such as Setonix brachyurus, or have adapted to a more tree-dwelling lifestyle, such Dendrolagus dorianus, Phascolarctos cinereus, Tarsipes rostratus and Trichosurus vulpecula, show a more radially symmetrical arrangement of ganglion cells. In animals that are climbers or that live in trees objects are not always perceived at a certain point, but rather the perception depends on their position at each moment. Thus, a radial arrengement is more advantageous than a horizontal visual streak. Except in the case of $P$. cinereus, in which the isodensity lines are displaced towards the ventral part of the retina, the rest of the species the distribution is centred around and above the optic nerve. This unusual position could be due to the fact that the koala does not usually leave the tree in which it takes refuge (koalas usually only leave trees when there is a shortage of food or when looking for a mate) as its slow movement make it an easy prey for predators. In this position, in order to feed, it looks to the upper branches and leaves, and so the concentric arrangement of ganglion cells in the ventral region would improve their upper visual field.

Between these two topographic patterns, there are the species that have a weak visual streak and a radial arrangement of ganglion cells. These are usually species that inhabit areas of dense vegetation when they need refuge or shelter but feed in more open areas, as is the case of Thylogale billardierii. Dasyurus hallucatus, which shows the same pattern, is a species which as well as living in open eucalyptus forests, also inhabit rocky areas where they take refuge in holes. Similarly, Sarcophilus harrisii can live in dense or open vegetation. Finally, Isoodon obesulus, has a mixed distribution pattern but has a low density of ganglion cells. Since this is an omnivorous species, which depends mainly on its olfactory sense and is active both during the day and at night, the low number of ganglion cells would suggest that vision is not the main sense necessary for its survival.

The area centralis is a region of high visual acuity present in a number of species, both herbivores and predators. With the exception of Macropus rufus, Lasiorhinus latrifons and Phascolarctos cinereus, all marsupials studied in this work have this specialization. One possible explanation for the absence of an area centralis is that these species do not use their upper members to feed but rather move their heads over the food. However, the species that present an area centralis have to locate their food and manipulate it with their upper members. Moreover, it is worth highlighting the existence of an area in M. rufus, that Hughes (1977) denominated anakatabatic area, which is present in other artiodactyls mammals. This is formed by an increase in neuronal 
density that runs perpendicularly from the temporal arm of the horizontal visual streak towards the dorsal retina giving rise to an L-shaped topographic pattern and may provide higher resolution to visualize the terrain on which they are feeding while moving. Hughes (1977) also noted that this area is much more evident in large sized animals. M. rufus can reach $180 \mathrm{~cm}$ in height when standing upright.

Concerning density gradient of ganglion cells between centre and periphery, the results vary according to species. This has been demonstrated by other authors in other vertebrate species such as birds (Dolan \& Fernández-Juricic, 2010). This is a parameter that highlights the importance of retinal specialization in the visualization of objects with respect to the peripheral retina. It is difficult to compare the gradients of these species according to their lifestyle, as the species studied have a wide range of lifestyles. However, Macropus rufus and Macropus eugenii, two species that have a visual streak and the strongest gradient of all the groups studied, live in groups. The need to visualize individuals in the group, above all using the visual streak, is probably very important for their survival, and takes preference over their peripheral vision.

Finally, taxonomical classification does not seem to be the parameter that determines either the topography of ganglion cells or the presence of an area centralis. This work demonstrates that the factors which generate greater evolutionary pressure are habitat and lifestyle. The fact that it is ecological and ethological factors that impose the structural characteristics on the retina has been corroborated in other aspects, such as the thickness of the photoreceptor layer compared to the thickness of the inner retina, morphological adaptations of the photoreceptors in order to improve sensitivity to colour, or the inner retina characteristics in terms of number and characteristics of the cells that are contained therein (Levine \& MacNichol, 1979; Wagner, 1990).

\section{CONCLUSIONS}

This paper presents a comparative analysis of the retinal topography of ganglion cells across Australian marsupial species. By combining this analysis with a consideration of lifestyle, the main conclusion is that retinal topography of ganglion cells are not determined by taxonomic classification, but rather by the functional requirements that ecological and ethological factors impose on the visual system. Moreover, the topographic pattern of ganglion cells in marsupials is closely related to the type of habitat: as the vegetation becomes denser, ganglion cells change from a distribution where the horizontal visual streak is predominant to a more radial distribution. Conversely, the presence of the área centralis in marsupials seems to be related to location and manipulation of food.

More comparative studies on the topography and presence of area centralis are required to establish the selective forces driving the evolution of retinal morphology in marsupials and their role in visual behavior.

\section{ACKNOWLEDGMENTS}

The authors are indebted to Rubén Vicedo Laporta and Noemí Victory Fiol for providing the images presented in Figures 2 and 3, respectively.

NAVARRO-SEMPERE, A.; SEGOVIA, Y. \& GARCÍA, M. Análisis comparativo de la topografía de las células ganglionares de la retina y ecología del comportamiento en marsupiales australianos. Int. J. Morphol., 36(1):248-257, 2018.

RESUMEN: La retina de los vertebrados muestra adaptaciones al entorno visual en el que evolucionan. Por lo tanto, existe una relación entre la distribución topográfica de las células de la retina, las estrategias de adaptación empleadas y el hábitat, por lo que los análisis de la topografía de las células ganglionares de la retina proporcionan información sobre la ecología del comportamiento de una especie. Aunque estas relaciones están bien documentadas en muchos vertebrados, incluidos los mamíferos, para especies dentro del orden marsupiales, no se conocen bien. Sin embargo, los marsupiales representan un grupo ideal para análisis comparativos de variaciones interespecíficas en el sistema visual de mamíferos porque contienen especies que varían tanto en el estilo de vida como en la preferencia del hábitat. En este trabajo se revisa la variación interespecífica en la topografía de células ganglionares de la retina en 13 especies de marsupiales australianos. Las especies que viven en hábitats abiertos tienen bandas visuales alargadas bien definidas. Por el contrario, los marsupiales que habitan en el bosque tienen rayas visuales mal definidas y una disposición más simétrica radialmente de los contornos de isodensidad de los CGR. Sin embargo, la organización y el grado de elongación de la banda visual varía considerablemente entre las especies. Los resultados indican que la aparente variación interespecífica está asociada con el patrón de actividad y el hábitat en oposición a las relaciones filogenéticas entre las especies.

PALABRAS CLAVE: Retina marsupial; Ecología visual; Topografía de células ganglionares. 


\section{REFERENCES}

Aplin, K. P. \& Archer, M. Recent Advances in Marsupial Systematics with A New Syncretic Classification. In: Archer, M. (Ed.). Possums and Opossums: Studies in Evolution. Chipping Norton, Surrey Beatty and Sons, 1987. pp.15-72.

Arrese, C.; Dunlop, S. A.; Harman, A. M.; Braekevelt, C. R.; Ross, W. M.; Shand, J. \& Beazley, L. D. Retinal structure and visual acuity in a polyprotodont marsupial, the fat-tailed dunnart (Sminthopsis crassicaudata). Brain Behav. Evol., 53(3):111-26, 1999.

Beazley, L. D. \& Dunlop, S. A. The evolution of an area centralis and visual streak in the marsupial Setonix brachyurus. J. Comp. Neurol., 216(2):211-31, 1983.

Bennettt, V. Fossil focus: Marsupial evolution - A limited story? Palaeontol. Online, 2(10):1-9, 2012. Available from: https:// www.palaeontologyonline.com/articles/2012/fossil-focus-marsupials/

Cardillo, M.; Bininda-Emonds, O. R. P.; Boakes, E. \& Purvis, A. A species-level phylogenetic supertree of marsupials. J. Zool., 264(1):11-31, 2004.

Collin, S. P. \& Partridge, J. C. Retinal specializations in the eyes of deepsea teleosts. J. Fish Biol., 49(sA):157-74, 1996.

Collin, S. P. \& Pettigrew, J. D. Retinal ganglion cell topography in teleosts: a comparison between Nissl-stained material and retrograde labelling from the optic nerve. J. Comp. Neurol., 276(3):412-22, 1988a.

Collin, S. P. \& Pettigrew, J. D. Retinal topography in reef teleosts. II. Some species with prominent horizontal streaks and high-density areae. Brain Behav. Evol., 31(5):283-95, 1988b.

Collin, S. P. A web-based archive for topographic maps of retinal cell distribution in vertebrates. Clin. Exp. Optom., 91(1):85-95, 2008.

Collin, S. P. Behavioural Ecology and Retinal Cell Topography. In: Archer, S. N.; Djamgoz, M. B. S; Loew, E. R.; Partridge, J. C. \& Vellarga, S. (Eds.). Adaptive Mechanism in the Ecology Of Vision. London, Chapman and Hall, 1999. pp.509-35.

Collins, L. R. Monotremes and Marsupials: A Reference for Zoological Institutions. Washington D. C., Smithsonian Institution Press, 1973.

Cronin, L. Cronin's Key Guide Australian Mammals. Sydney, Editorial Allen \& Unwin, 2008

Dickman, C. R.; Predavec, M. \& Downey, F. J. Long-range movements of small mammals in arid Australia: implications for land management. J. Arid Environ., 31(4):441-52, 1995.

Dolan, T. \& Fernández-Juricic, E. Retinal ganglion cell topography of five species of ground-foraging birds. Brain Behav. Evol., 75(2):11121, 2010.

Dunlop, S. A.; Ross, W. M. \& Beazley, L. D. The retinal ganglion cell layer and optic nerve in a marsupial, the honey possum (Tarsipes rostratus). Brain Behav. Evol., 44(6):307-23, 1994

Everaardt, A. The Impact of Fire Upon the Size and Flowering of Three Honey Possum Foodplants at the Western End of the Fitzgerald River National Park, Western Australia. Thesis for the Degree of Doctor of Philosophy. Perth, Murdoch University, 2003.

Flannery, T. F. \& Seri, L. Dendrolagus scottae n.sp. (Marsupialia: Macropodidae): A new tree-kangaroo from Papua New Guinea. Rec. Aust. Mus., 42(3):237-45, 1990

Freeman, B. \& Tancred, E. The number and distribution of ganglion cells in the retina of the brush-tailed possum, Trichosurus vulpecula. J. Comp. Neurol., 177(4):557-67, 1978.

Geiser, F.; Augee, M. L.; McCarron, H. \& Raison, J. K. Correlates of torpor in the insectivorous dasyurid marsupial Sminthopsis murina. Aust. Mammal., 7:185-191, 1984.

Green, R. H. Notes on the Devil (Sarcophilus harrisi) and the Quoll (Dasyurus viverrinus) in North-Eastern Tasmania. Launceston City, Museum Committee, 1967.

Grzimek, B. Grzimek's Animal Encyclopedia. New York, Van Nostrand Reinhold, 1975.
Harman, A. M.; Nelson, J. E.; Crewther, S. G. \& Crewther, D. P. Visual acuity of the northern native cat (Dasyurus hallucatus)--behavioural and anatomical estimates. Behav. Brain Res., 22(3):211-6, 1986.

Hughes, A. A quantitative analysis of the cat retinal ganglion cell topography. J. Comp. Neurol., 163(1):107-28, 1975.

Hughes, A. New Perspectives in Retinal Organization. In: Osbdorne, N. \& Chader, G. (Eds.). Progress in Retinal Research (Eds.) Oxford, Pergamon Press, 1985. pp.243-313.

Hughes, A. The Topography of Vision in Mammals of Contrasting Life Style: Comparative Optics and Retinal Organization. In: Crescitelli, F. (Ed.). Handbook of Sensory Physiology. New York, Springer, 1977. pp.613-756.

Inzunza, O.; Bravo, H.; Smith, R. L. \& Angel, M. Topography and morphology of retinal ganglion cells in Falconiforms: a study on predatory and carrion-eating birds. Anat. Rec., 229(2):271-7, 1991.

Jarman, P. J. Social behaviour and organization in the Macropodidae. Adv. Study Behav., 20:1-50, 1991.

Johnson, K. A. \& Rose, R. W. Tasmanian pademelon, Thylogale billardierii. In: Strahan, R. (Ed.). The Mammals of Australia. Sydney, Reed Book, 1995. pp.394-6.

Johnson, K. A. Spatial and Temporal use of habitat by the red-necked pademelon, Thylogale thetis (Marsupialia: Macropodidae). Aust. Wildl. Res., 7(2):157-66, 1980.

Jones, M. E. \& Barmuta, L. A. Niche differentiation among sympatric Australian dasyurid carnivores. J. Mammal., 81(2):434-47, 2000.

Kitchener, D. J. The importance of shelter to the quokka, Setonix brachyurus (Marsupialia), on Rottnest Island. Aust. J. Zool., 20(3):281-99, 1972.

Lentle, R. G. Feeding Strategies of the Tammar Wallaby (Macropus eugenii Desmarest). Ph.D. Thesis. Palmerston, Massey University, 1998.

Levine, J. S. \& MacNichol, E. F. Jr. Visual pigments in teleost fishes: effects of habitat, microhabitat, and behavior on visual system evolution. Sens. Processes, 3(2):95-131, 1979.

Luo, Z. X.; Ji, Q.; Wible, J. R. \& Yuan, C. X. An Early Cretaceous tribosphenic mammal and metatherian evolution. Science, 302(5652):1934-40, 2003.

Mengual, R.; García, M.; Segovia, Y. \& Pertusa, J. F. Ocular morphology, topography of ganglion cell distribution and visual resolution of the pilot whale (Globicephala melas). Zoomorphology, 134(2):339-49, 2015.

Mengual, R.; Segovia, Y. \& García, M. Morphological characteristics of pilot whales retina (Globicephala melas; Traill, 1809) and their relationship to habitat. Int. J. Morphol., 32(4):1399-406, 2014.

Meyer, D. B. The Avian Eye and its Adaptations. In: Crescitelli, F. (Ed.) Handbook of Sensory Physiology, The Visual System in Vertebrates. Berlin, Springer, 1977. pp.549-611.

Morton, S. R. An Ecological Study of Sminthopsis crassicaudata (Marsupialia: Dasyuridae). Reproduction and Life History. Aust. Wildl. Res., 5(2):183-211, 1978

Moyal, A. Koala: A Historical Biography. Melbourne, CSIRO Publishing, 2008.

Nicholls, D. G. Daily and seasonal movements of the quokka Setonix brachyurus (Marsupialia), on Rottnest Island. Aust. J. Zool., 19(3):215-26, 1971.

Nilsson, M. A.; Arnason, U.; Spencer, P. B. \& Janke, A. Marsupial relationships and a timeline for marsupial radiation in South Gondwana. Gene, 340(2):189-96, 2004.

Nilsson, M. A.; Churakov, G.; Sommer, M.; Tran, N. V.; Zemann, A.; Brosius, J. \& Schmitz, J. Tracking marsupial evolution using archaic genomic retroposon insertions. PLoS Biol., 8(7):e1000436, 2010.

Nowak, R. M. Walker's Mammals of the World. $6^{\text {th }}$ ed. Baltimore, Johns Hopkins University Press, 1999. 
Oakwood, M. Spatial and social organization of a carnivorous marsupial Dasyurus hallucatus (Marsupialia: Dasyuridae). J. Zool., 257(2):23748, 2002.

Paull, D. J. Southern Brown Bandicoot, Isoodon obesulus. In: Van Dyck, S. \& Strahan, R. (Eds.). The Mammals of Australia. Sydney, Reed New Holland, 2008. pp.180-2

Peichl, L.; Behrmann, G. \& Kröger, R. H. For whales and seals the ocean is not blue: a visual pigment loss in marine mammals. Eur. J. Neurosci., 13(8):1520-8, 2001.

Procter-Gray, E. \& Ganslosser, U. The individual behaviors of Lumholtz's tree-kangaroo: Repertoire and taxonomic implications. J. Mammal., 67(2):343-52, 1986.

Ride, W. D. L. Guide to the Native Mammals of Australia. Melbourne, Oxford University Press, 1970.

Russell, E. M. \& Rentree, M. B. Tarsipedidae. In: Walton, D. W. \& Richardson, B. J. (Eds.). Fauna of Australia. Volume IB. Mammalia. Chapter 33. Canberra, Australian Government Publishing Service, 1989. pp.769-82.

Schiviz, A. N.; Ruf, T.; Kuebber-Heiss, A.; Schubert, C. \& Ahnelt, P. K. Retinal cone topography of artiodactyl mammals: influence of body height and habitat. J. Comp. Neurol., 507(3):1336-50, 2008.

Schluessel, V.; Kraniotakes, H. \& Bleckmann, H. Visual discrimination of rotated 3D objects in Malawi cichlids (Pseudotropheus sp.): a first indication for form constancy in fishes. Anim. Cogn., 17(2):359-71, 2014.

Schmid, K. L.; Schmid, L. M.; Wildsoet, C. F. \& Pettigrew, J. D. Retinal topography in the koala (Phascolarctos cinereus). Brain Behav. Evol., 39(1):8-16, 1992.

Taggart, D. A. \& Temple-Smith, P. D. Southern Hairy-Nosed Wombat. In: Van Dyke, S. \& Strahan, R. (Eds.). The Mammals of Australia. Sidney, Reed New Holland, 2008. pp.204-6.

Tancred, E. The distribution and sizes of ganglion cells in the retinas of five Australian marsupials. J. Comp. Neurol., 196(4):585-603, 1981.

Temple, S.; Hart, N. S.; Marshall, N. J. \& Collin, S. P. A spitting image: specializations in archerfish eyes for vision at the interface between air and water. Proc. Biol. Sci., 277(1694):2607-15, 2010.

Vorobyev, M. Coloured oil droplets enhance colour discrimination. Proc. Biol. Sci., 270(1521):1255-61, 2003.

Wagner, H. J. Retinal Structure of Fishes. In: Douglas, R. \& Djangoz, M. (Eds.). The Visual System of Fish. Amsterdam, Springer, 1990. pp.10957.

Wagner, H. J.; Fröhlich, E.; Negishi, K. \& Collin, S. P. The eyes of deepsea fish. II. Functional morphology of the retina. Prog. Retin Eye Res., 17(4):637-85, 1998.

Walls, G. L. The Vertebrate Eye and its Adaptive Radiation. New York, Hafner Publishing Company, 1942.

Warrant, E. Vision in the dimmest habitats on earth. J. Comp. Physiol. A Neuroethol. Sens. Neural Behav. Physiol., 190(10):765-89, 2004.

Wells, R. Vombatidae. In: Walton, D. W. \& Richardson, B. J. (Eds.). Fauna of Australia. Volume I. Mammalia. Canberra, Australian Government Publishing Service, 1989. pp.755-68.

Wells, R. Southern Hairy-Nosed Wombat Lasiorhinus latifrons. In: Strahan, R. (Ed.). Mammals of Australia. Chatswood, Reed Books, 1995. pp.202-3.

Withers, P. C.; Richardson, K. C. \& Wooller, R. D. Metabolic physiology of euthermic and torpid honey possums, Tarsipes rostratus. Aust. J. Zool., 37(6):685-93, 1990.

Wong, R. O.; Wye-Dvorak, J. \& Henry, G. H. Morphology and distribution of neurons in the retinal ganglion cell layer of the adult tammar wallaby--Macropus eugenii. J. Comp. Neurol., 253(1):1-12, 1986.

Wooller, R. D. \& Wooller, S. J. The role of non-flying animals in the pollination of Banksia nutans. Aust. J. Bot., 51(5):503-7, 2003.

Wroe, S.; McHenry, C. \& Thomason, J. Bite club: comparative bite force in big biting mammals and the prediction of predatory behaviour in fossil taxa. Proc. Biol. Sci., 272(1563):619-25, 2005.
Corresponding author:

Yolanda Segovia Huertas

Department of Biotechnology

University of Alicante

Apartado 99

03080 Alicante

SPAIN

Email: Yolanda.segovia@ua.es

Received: 28-07-2017

Accepted: 19-12-2017 